\title{
Effects of Herbicide Atrazine in Experimental Animal Models
}

\author{
Grasiela D.C. Severi-Aguiar ${ }^{2}$ and Elaine C.M. Silva-Zacarin ${ }^{1}$ \\ ${ }^{1}$ Laboratório de Biologia Estrutural e Funcional (LABEF), \\ Universidade Federal de São Carlos - UFSCAR, Sorocaba, São Paulo; \\ 2Programa de Pós-Graduação em Ciências Biomédicas, Centro Universitário Hermínio \\ Ometto, UNIARARAS, Araras, São Paulo \\ Brazil
}

\section{Introduction}

Atrazine (2-chloro-4-ethylamino-6-isopropylamino-1,3,5-triazine) is a widely used herbicide in many countries for the control of broadleaf and grassy weeds in agricultural crops. The State of São Paulo, located in Brazil Southeast, is an important sugarcane, soybean and corn producing area with high use of chemicals in agriculture and potential risk of environmental contamination because of the pesticide dissemination, among them the atrazine (ATZ) leaching to groundwater (Cerdeira et al., 2005).

The prolonged use of ATZ and its persistence involves the risk of its retention in crops and soils; moreover, these compounds may also pass from surface to ground waters (Figure 1). In this way, ever-increasing agriculture has caused contamination of natural water sources (Mundiam et al., 2011). The maximum contaminant levels for the most of triazines in drinking water are 3 parts per billion ( $\mu \mathrm{g} / \mathrm{L})$ (Costa Silva et al., 2010).

Some European countries have included ATZ on the list of pesticide residues to be controlled because it is a potential contaminant due to its chemical characteristics, including lipophilicity, slow hydrolysis, moderate to low water solubility, and high solubility in organic solvents with high absorption by organic matter, clay, and fat tissues (Ross et al., 2009). The lack of data about the effects of ATZ metabolites has prompted the U.S. Environmental Protection Agency (U.S. EPA) to state that the toxicity of atrazine's metabolites is equivalent to that of its parent compound and that exposure to these metabolites should be taken into account for risk assessment purposes (Ralston-Hooper et al., 2009).

Mohammad \& Itoh (2011) presented the relative risk of various scenarios of exposure and recovery with an aquatic test organism submitted a long-term exposure to herbicides and demonstrated the toxicity of isolated or mixtures of ATZ at different concentrations. However, the patterns of accumulation of xenobiotics vary depending on the organism, characteristics of the chemical compound, quantity of this substance present in the environment, and the balance between assimilation and metabolic rates (Nwani et al., 2011). 
It is necessary to study the effects of atrazine exposure in a great variety of experimental animal models in order to understand its action in the organisms and their target organs. In this context, it is very important to verify the effect of high concentration of herbicides in animal tests as positive controls. Saal \& Welshons (2006) related the importance of positive controls in toxicological research to determine whether conclusions from experiments that report no significant effects in low-dose of the toxicant are valid or false.

Since in the last decade many efforts have resulted in intensive research about action of ATZ in various organisms, it could be necessary to identify morphological, molecular, biochemical or physiological biomarkers that detect biological effects of this triazine herbicide on the organisms (Campero et al., 2007). So we present in this chapter an extensive bibliographical review about this herbicide in animal tissues, focusing some target-organs, in order to gain insight into its cellular mechanisms, highlighting the results obtained by our research group.

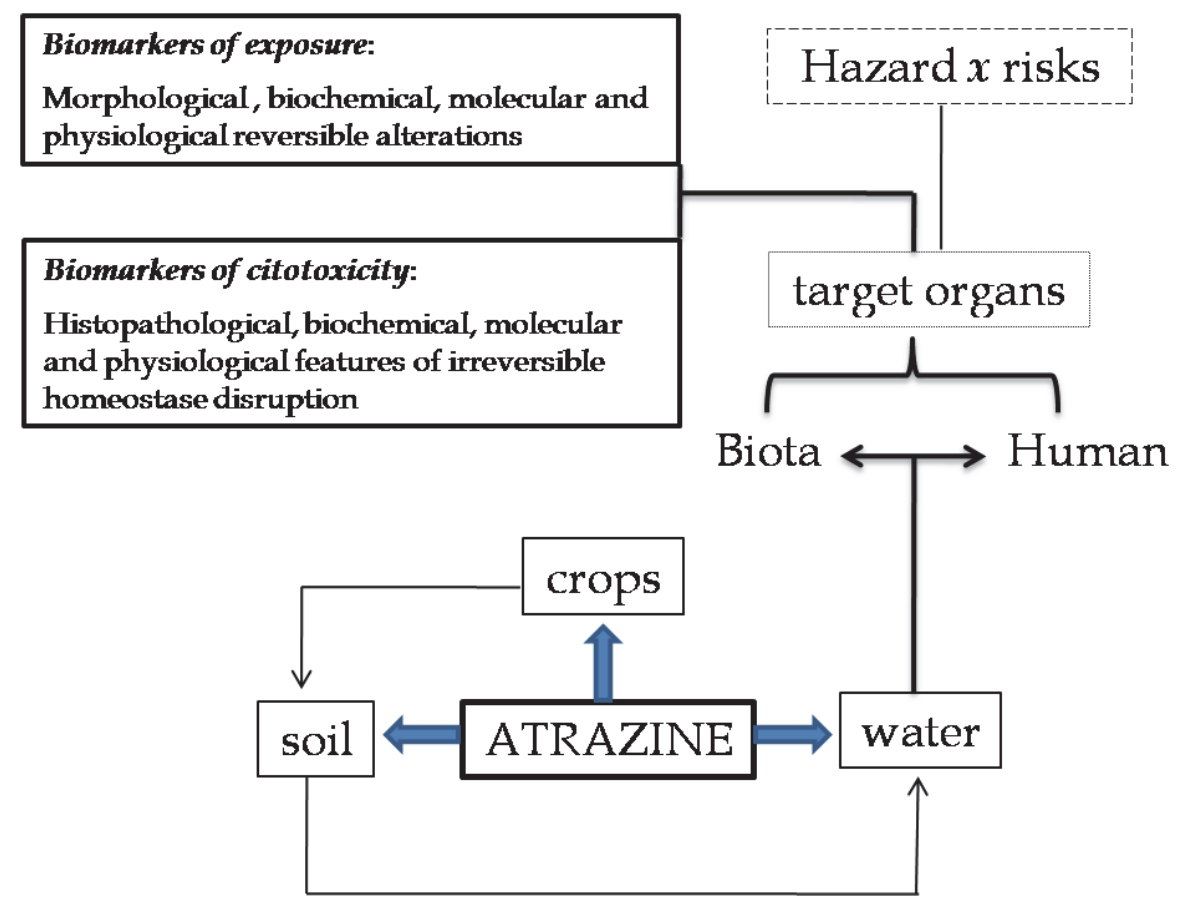

Fig. 1. Environmental contamination way of atrazine. Studies about biota and human health hazard are the basis for risk assessment and, in this context, cellular markers in target organs from organisms exposed to this herbicide could be used in monitoring programs.

\section{Morphological and molecular alterations caused by ATZ}

\subsection{Hepatotoxicity}

In liver, organ responsible for detoxification process, our researches with Wistar rats orally exposed to $400 \mathrm{mg} / \mathrm{kg}$ body weight (bw) of ATZ for 14 days, showed reduced accumulation 
of hepatic glycogen and early symptoms of cytotoxicity. This event is attributed to the hepatotoxic effect of ATZ, which inhibits the activity of key enzymes of glyconeogenesis such as hexokinase, glycogen synthase, and glucokinase (Glusczak et al., 2006) and it can explain decrease in animals' body weight observed in our study. This finding agrees with Curic et al. (1999), who studied fish exposed to low doses of ATZ (2 mg/ kg) for two weeks and observed the decrease of glycogen and the increase of lipids in the liver.

On the other hand, no differences in glycogen or lipid storage were noted in livers of Xenopus laevis tadpoles exposed to both atrazine concentrations 200 and $400 \mu \mathrm{g} / \mathrm{L}$ (Zaya et al., 2011). Livers of ATZ-exposed tadpoles were significantly smaller and those from $400 \mu \mathrm{g} / \mathrm{L}$-exposed tadpoles had higher numbers of activated caspase-3 immuno-positive cells suggesting increased rates of apoptosis. The changes noted in body and organ size at 200 and $400 \mu \mathrm{g} / \mathrm{L}$ ATZ indicated that exposure throughout development compromised the tadpoles. Additionally, fat body size decreased significantly after exposure to 200 and $400 \mu \mathrm{g} / \mathrm{L}$ of ATZ, although this organ still contained some lipid and lacked any pathology. Zaya et al. (2011) suggested that significant reductions in fat body size could potentially decrease their ability to survive the stresses of metamorphosis or reduce reproductive fitness as frogs rely on lipid storage for these processes.

In male Japanese quail (Coturnix japonica), vacuolar degeneration in liver was observed at high doses of ATZ (500 mg/kg bw) ingested orally by 45 days (Hussain et al., 2011). Additionally, biliary hyperplasia and mild renal tubular necrosis were observed in these quails. In our studies with Wistar rats orally exposed to $400 \mathrm{mg} / \mathrm{kg}$ body weight (bw) of ATZ for 14 days, similar data were observed in liver and renal tubular necrosis was also observed.

Zebrafish (Danio rerio) is other model organism that presented histopathological effects in liver, which were induced by atrazine exposure. Yuanxiang et al. (2011) found seven proteins that were upregulated $>2$ - fold, whereas 6 protein were downregulated $>2$-fold, after 10 and $1000 \mu \mathrm{g} / 1$ ATZ exposures in zebrafish for 14 days. They suggested that these changes in protein regulation were associated with a variety of cellular biological processes, such as response to oxidative stress, oncogenesis and others.

Another example of cellular biological process that could be changed in response to atrazine exposure is the lipid metabolism and insulin resistance. Study performed in SpragueDawley rats treated for 5 months with vehicle or ATZ (30 or $300 \mu \mathrm{g} \mathrm{kg}^{-1} \mathrm{day}^{-1}$ ), supplied in drinking water, showed prominent accumulation of lipid droplets in the livers of ATZtreated rats (Lim et al., 2009). By means of transmission electron microscopy, some liver mitochondria from the ATZ-treated group showed partially disrupted cristae. Despite the fact that mitochondrial morphology was altered in liver and, additionally, in muscle, protein expression levels of mitochondrial OXPHOS complex subunits in liver and muscle tissues were not changed significantly by ATZ administration. Since no treatment-related changes in food or water intake or physical activity were observed at any point during the study, Lim et al. (2009) believe that the development of insulin resistance by ATZ might be related to energy metabolism and they suggest that long-term exposure to the herbicide ATZ might contribute to the development of insulin resistance and obesity, particularly where a highfat diet is prevalent. 


\subsection{Reproductive toxicity}

In review of Sifakis et al. (2011) about pesticide exposure and health, related issues in male and female reproductive system have been presented and they showed that ATZ seems to have estrogenic and anti-androgenic properties.

Our research group evaluated histopathological effects of low and high doses of ATZ in ovary and testicles from exposed Wistar rats and the compilation of data are presented in the Table 1.

Testicular lesions observed in our studies (Table 1) also be detected, associated with reduced germ cell numbers, in teleost fish, amphibians, reptiles, and mammals; and induces partial and/or complete feminization in fish, amphibians, and reptiles (Hayes et al., 2011). Then, ATZ is an endocrine disruptor that demasculinizes and feminizes the gonads of male vertebrates by means of the reduction in androgen levels and the induction of estrogen synthesis - demonstrated in fish, amphibians, and reptiles - that represent plausible and coherent mechanisms to explain these effects, according to Hayes et al. (2011). ATZ reduce testicular testosterone in male rats and it was associated with poor semen quality (Sifakis et al., 2011).

\begin{tabular}{|c|c|c|c|}
\hline \multicolumn{4}{|c|}{ Morphological alterations induced by atrazine oral exposure } \\
\hline \multicolumn{2}{|c|}{ Ovaries } & \multicolumn{2}{|c|}{ Testis } \\
\hline $0,75 \mathrm{mg} / \mathrm{kg}$ & $400 \mathrm{mg} / \mathrm{kg}$ & $0,75 \mathrm{mg} / \mathrm{kg}$ & $400 \mathrm{mg} / \mathrm{kg}$ \\
\hline $\begin{array}{l}\text { Primordial follicles } \\
\text { without alterations }\end{array}$ & $\begin{array}{l}\text { Primordial follicles } \\
\text { without alterations }\end{array}$ & $\begin{array}{c}\text { Normal } \\
\text { histoarchitecture }\end{array}$ & $\begin{array}{c}\text { Disorganized } \\
\text { histoarchitecture }\end{array}$ \\
\hline $\begin{array}{l}\text { Primary follicles } \\
\text { without alterations }\end{array}$ & $\begin{array}{l}\text { Primary follicles } \\
\text { without alterations }\end{array}$ & $\begin{array}{c}\text { Absence of } \\
\text { degeneration in } \\
\text { seminiferous } \\
\text { epithelium }\end{array}$ & $\begin{array}{l}\text { Degeneration in } \\
\text { some areas of the } \\
\text { seminiferous } \\
\text { epithelium }\end{array}$ \\
\hline $\begin{array}{l}\text { Presence of some } \\
\text { multioocytic } \\
\text { Preantral follicles }\end{array}$ & $\begin{array}{c}\text { Preantral follicles } \\
\text { with disorganized } \\
\text { granulose layer } \\
\text { and/or a } \\
\text { degenerating } \\
\text { oocyte }\end{array}$ & $\begin{array}{l}\text { Germinative cells } \\
\text { keep their typical } \\
\text { morphology }\end{array}$ & $\begin{array}{l}\text { Some germinative } \\
\text { cells presented } \\
\text { apoptotic or } \\
\text { necrosis features }\end{array}$ \\
\hline $\begin{array}{c}\text { Antral follicles } \\
\text { without alterations }\end{array}$ & $\begin{array}{l}\text { Presence of some } \\
\text { Antral follicles } \\
\text { with a } \\
\text { degenerating } \\
\text { oocyte }\end{array}$ & $\begin{array}{l}\text { Germinative cells } \\
\text { were not released to } \\
\text { tubular lumen }\end{array}$ & $\begin{array}{l}\text { Releasing of } \\
\text { germinative cells to } \\
\text { the tubular lumen }\end{array}$ \\
\hline $\begin{array}{l}\text { Atretic antral } \\
\text { follicles with } \\
\text { intensification of } \\
\text { apoptosis in } \\
\text { granulose cells }\end{array}$ & $\begin{array}{l}\text { High intensity of } \\
\text { apoptosis in the } \\
\text { granulose cells of } \\
\text { Atretic antral } \\
\text { follicles }\end{array}$ & $\begin{array}{l}\text { Intertubular tissue } \\
\text { around seminiferous } \\
\text { tubules remained } \\
\text { intact }\end{array}$ & $\begin{array}{c}\text { Intertubular tissue } \\
\text { around } \\
\text { seminiferous } \\
\text { tubules remained } \\
\text { intact }\end{array}$ \\
\hline
\end{tabular}

Table 1. Histopathological analysis of ovaries and testis from Wistar rats submitted to subchronic oral exposure: $0,75 \mathrm{mg}$ atrazine $/ \mathrm{kg} /$ day during 30 days; and subchronic oral exposure: $400 \mathrm{mg}$ atrazine $/ \mathrm{kg} /$ day during 14 days. 
A study developed by Hussain et al. (2011) that intended to determine the pathological and genotoxic effects of ATZ in male Japanese quail (Coturnix japonica) demonstrated that testis from ATZ treated birds were comparatively smaller in size and seminiferous tubules in group treated with $500 \mathrm{mg} / \mathrm{kg}$ bw exhibited decreased number of spermatocytes, necrotic nuclei of spermatids, and lesser number or absence of spermatozoa.

A significant dose dependent induction in the levels of mRNA expression of genes of steroidogenic acute regulatory protein (STAR), cytochrome P450-11A1, 3 $\beta$-hydroxysteroid dehydrogenase ( $3 \beta-H S D)$, and other steroidogenic proteins were observed in cells exposed to ATZ. These data suggest the applicability of these selected marker genes of steroidogenesis as an indicator of short term exposure of ATZ induced rat testicular toxicity in interstitial Leydig cells (ILCs) (Abarikwu et al., 2011).

Pogrmic-Majkic et al. (2010) examined Leydig cells treated for $24 \mathrm{~h}$ with the concentrations $0.001,1,10,20$, and $50 \mu \mathrm{M}$ of ATZ and they observed increased basal and human chorion gonadotropin-stimulated testosterone production and accumulation of cAMP in the medium of treated cells. The stimulatory action of atrazine on androgen production but not on cAMP accumulation was abolished in cells with inhibited protein kinase A. They observed that Leydig cells obtained from rats treated with $200 \mathrm{mg}$ ATZ/ kg body weight, by gavage, during the first 3 days of treatment, stimulated the expression of mRNA transcripts for steroidogenic factor-1, steroidogenic acute regulatory protein, cytochrome P450(CYP)17A1, and 17b-hydroxysteroid dehydrogenase (HSD), as well as the activity of CYP17A1 and $17 \mathrm{bHSD}$ and cAMP accumulation and androgen production. However, this behavior is followed by a decline during further treatment ( 6 days). These results indicate that ATZ has a transient stimulatory action on cAMP signaling pathway in Leydig cells, leading to facilitated androgenesis.

ATZ exposure (120 or $200 \mathrm{mg} / \mathrm{kg}$ body weight ATZ orally for 7 and 16 days) has a dosedependent adverse effect on the testicular and epididymal sperm numbers, motility, viability, morphology, and daily sperm production in rats (Abarikwu et al., 2009). Although the testis of the ATZ -treated animals appear normal, few tubules had mild degeneration with the presence of defoliated cells, similar to observed in our research group for rat testis (Table 1). Likewise, no perceptible morphological changes were observed in the epididymis. The results suggest that ATZ impairs reproductive function and elicits a depletion of the antioxidant defense system in the testis and epididymis, indicating the induction of oxidative stress. Glutathione (GSH) and glutathione-S-transferase (GST) activities were elevated in the high-dose group, whereas the activity of superoxide-dismutase (SOD), catalase (CAT); ascorbate (AA), and malondialdehyde (MDA) levels and hydrogen peroxide production were unchanged in the testis during the 7-day exposure protocol. When ATZ treatment was increased to 16 days, GSH levels remained unchanged, but lipid peroxidation levels were significantly increased in both the testis and epididymis. This corresponded to the significant diminution in the activities of GST and SOD. CAT activities were unaffected in the testis and then dropped in the epididymis. These experiments performed by Abarikwu et al. (2009) was important to understand the antioxidant defense system in the testis and epididymis; and it is interesting to note that ATZ can also affect mitochondrial electron transport and oxidative stress in the insect Drosophila melanogaster (Thornton et al., 2010). 
Eggs of alligator Caiman latirostris, at stage 20 of embryonic development, were exposed to $0,02 \mathrm{ppm}$ of ATZ and incubated at $33^{\circ} \mathrm{C}$ resulted in male hatchlings. Tortuous seminiferous tubules with increased perimeter, disrupted distribution of peritubular myoid cells (desmin positive), and emptied tubular lumens characterized the testis of pesticide-exposed Caiman (Rey et al., 2009).

ATZ is a known ovarian toxicant which increase progesterone (P4) secretion and induce luteal cell hypertrophy following repeated administration. The aim of Taketa (2011) study group was to define the pathways by which these compounds exerted their effects on the ovary and hypothalamic-pituitary-gonadal (HPG) axis. They demonstrated that $300 \mathrm{mg}$ $\mathrm{ATZ} / \mathrm{kg}$ were orally given daily from proestrus to diestrus in normal cycling rats resulted in significant increased serum P4 levels, upregulation of the follow steroidogenic factors: scavenger receptor class B type I, steroidogenic acute regulatory protein, P450 cholesterol side-chain cleavage and $3 \beta$-hydroxysteroid dehydrogenase (HSD), and so downregulation of luteolytic gene 20a-HSD. ATZ may directly activate new corpora lutea by stimulating steroidogenic factor expressions and the authors suggest that multiple pathways mediate its effects the HPG axis and luteal P4 production in female rats in vivo.

One of the molecular events that may be triggered by stressful conditions, like pesticide exposure, is the synthesis of heat shock proteins (HSP). Additionally to histophatological analysis of rat ovaries (Table 1), our studies also emphasized the immunohistochemical labeling of $90 \mathrm{KD}$ heat shock protein (HSP 90) in order to evaluate the role played by this protein in the ovary, under stressed conditions induced by ATZ exposure. Our results indicated that atrazine induced impaired folliculogenesis, increased follicular atresia and HSP90 depletion in female rats submitted to subacute treatment, while the subchronic treatment with the lowest dose of ATZ could compromise the reproductive capacity reflected by the presence of multioocytic follicle and stress-inducible HSP90 (Juliani et al., 2008).

Experiments developed by our research group also showed that low doses of ATZ, which does not affect estrous cyclicity, induced a higher HSP70 expression in cells of the oviduct when compared to the control group, indicating that HSP70 may be acting in the tissue response to stress caused by chronic exposure to the herbicide. In subacute exposure, with the dose that disrupts the estrous cycle, the expression of HSP70 was higher than the control group and the subchronic treatment (Figure 2), probably indicating a major protective function of HSP70 in addition to the estrogen receptor baseline level maturation. In literature, HSP70 is related to the maturation of the estrogen receptor in the oviduct (Mariani et al., 2000). We concluded that the increased expression of HSP70 induced by ATZ is mainly related to the protective effect of these chaperones in response to chemical stress generated by exposure to this herbicide.

\subsection{Glandular alterations}

Due to the adrenal gland is reported to be the most common endocrine organ associated with chemically induced lesions, our research group also evaluated adrenal glands of adult rats submitted to subacute and subchronic treatment with this herbicide, respectively. The morphological and histochemical analyses were performed and the results indicated that the subacute treatment induced drastic alterations in the cortex of the adrenal glands as well as 


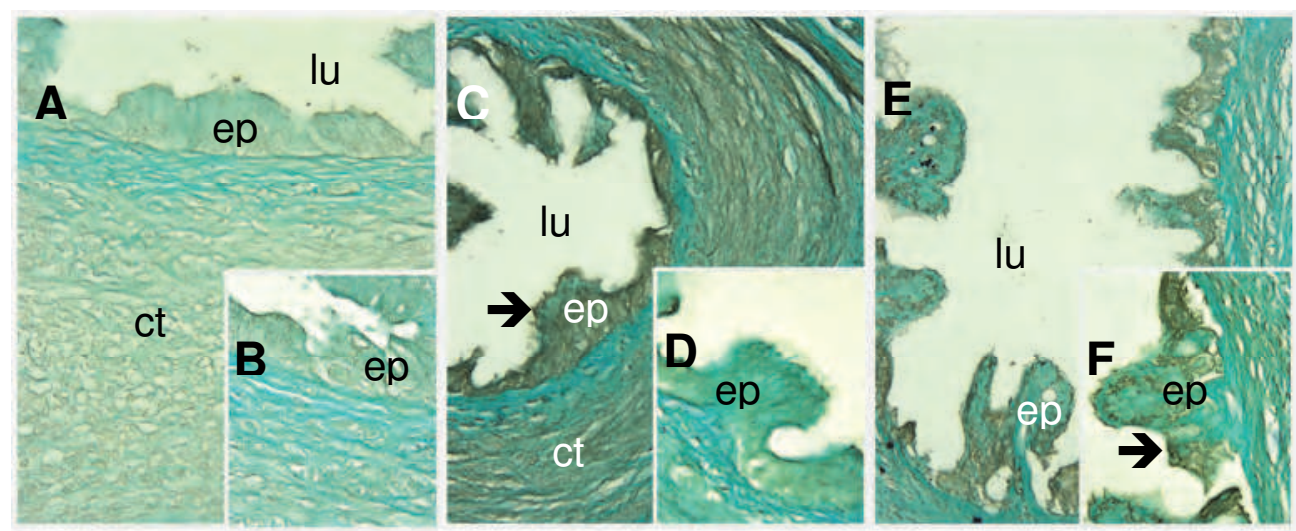

Fig. 2. Immunohistochemical detection of HSP70 (Heat Shoch Protein - 70) in oviduct from Wistar rats. A-B) Control Group; C-D) Experimental group submitted to subchronic oral exposure: $0,75 \mathrm{mg}$ atrazine $/ \mathrm{kg} /$ day during 30 days; E-F) Experimental group submitted to subchronic oral exposure: $400 \mathrm{mg}$ atrazine $/ \mathrm{kg} /$ day during 14 days. Oviducts present different degrees of immunopositive reaction (brown color) in epithelium (ep) and connective tissue (ct). Arrows indicate areas with high imunolabeling of HSP70. A, C, E Magnification $=200 x ; B, D, F-$ Magnification $=400 x$.

in the medullar region. The subchronic treatment with the low dose of ATZ caused slight morphological alterations in the cortex of adrenal glands, but not in the medullar region. The histochemical analyses showed abnormal accumulations of lipid droplets mainly in the Reticularis Zona of the adrenal cortex suggesting alteration in the steroidogenesis process that occur in this region (Figure 3).

Foradori et al. (2011) demonstrated that high doses of ATZ (200mg/kg), administered for 4 days, suppress luteinizing hormone (LH) release and increase adrenal hormones levels. Considering the known inhibitory effects of adrenal hormones on the hypothalamopituitary-gonadal axis, the authors investigated the possible role that the adrenal gland has in mediating ATZ inhibition of LH release and observed that adrenolectomy had no effect on ATZ inhibition of the LH surge but prevented the ATZ disruption of pulsatile LH release. These data indicate that ATZ selectively affects the LH pulse generator through alterations in adrenal hormone secretion. Adrenal activation does not play a role in ATZ's suppression of the LH surge and therefore, ATZ may work centrally to alter the preovulatory LH surge in female rats.

\subsection{Genotoxicity}

Although the toxic properties of ATZ are well known, there is not a consensus about the genotoxic effects of ATZ. On aquatic organisms they are rather scarce. To evaluate the genotoxic effects of ATZ and an ATZ-based herbicide (Gesaprim $\left.{ }^{\circledR}\right)$ on a model fish species Carassius auratus L., 1758, (Pisces: Cyprinidae) using the micronucleus test and the comet assay in peripheral blood erythrocytes, fish were exposed to 5, 10 and $15 \mu \mathrm{g} / \mathrm{L}$ ATZ and to its commercial formulation for 2, 4 and 6 days (Cavas, 2011). The results revealed significant increases in the frequencies of micronuclei and DNA strand breaks in erythrocytes of $C$. 
auratus, following exposure to commercial formulation of ATZ and thus demonstrated the genotoxic potential of this pesticide on fish.
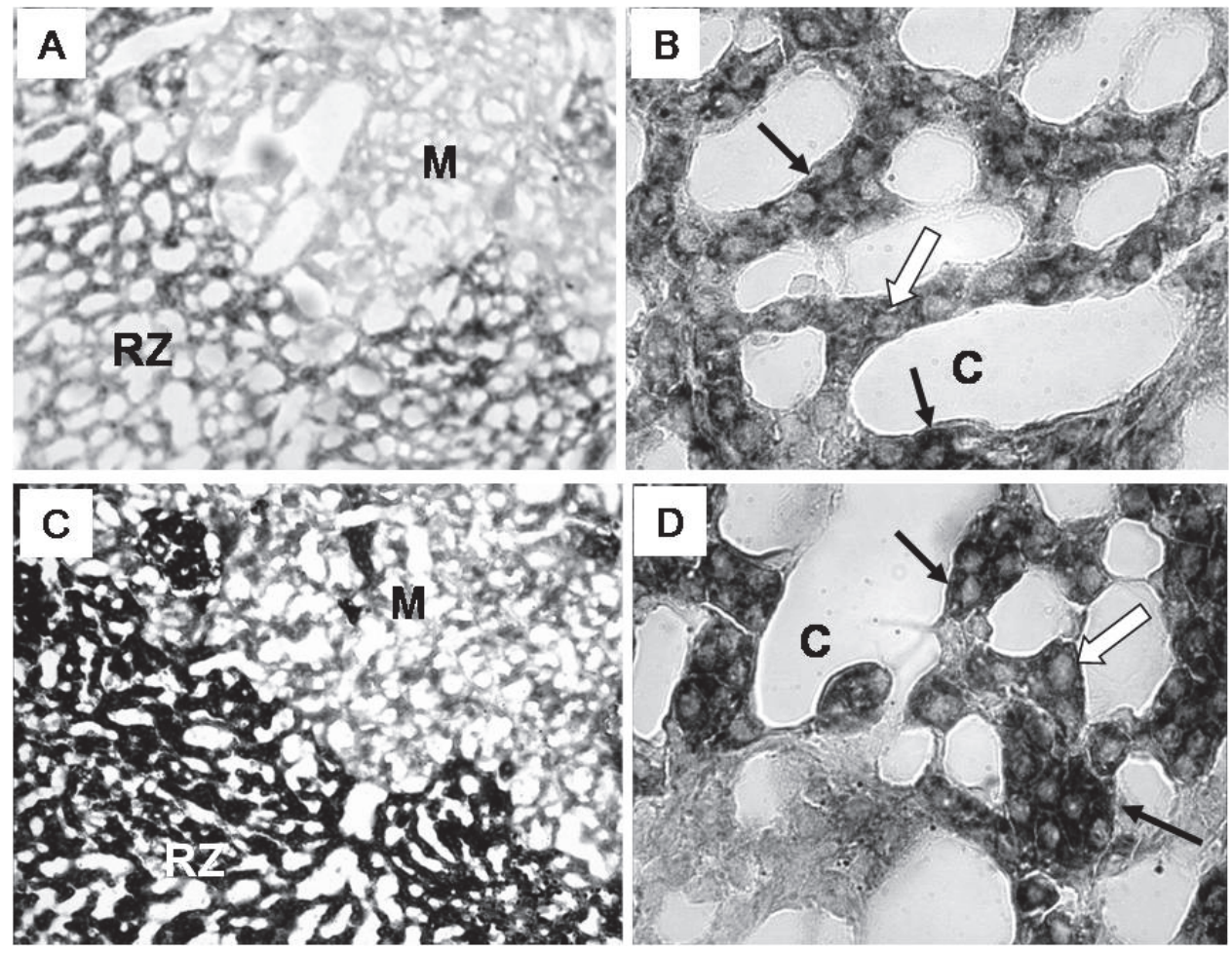

Fig. 3. Cryosections of adrenal gland from Wistar rats, stained with Sudam Black. The darkbrown color indicates the presence of lipids in the Reticularis Zone (RZ) but not in the Medullar region (M). A-B) Control Group; C-D) Experimental group submitted to subchronic oral exposure: $0,75 \mathrm{mg}$ atrazine $/ \mathrm{kg} /$ day during 30 days. In (B) and (D), lipids in cells of Reticularis Zone are indicated with arrows (black arrow = the strongest intensity; white arrow $=$ strong intensity). A, C - Magnification $=200 x ; B, D-$ Magnification $=400 x$

Significantly longer comet tails of DNA damage in leukocytes and isolated hepatocytes of male Japanese quail (Coturnix japonica) were recorded with $500 \mathrm{mg} / \mathrm{kg}$ bw ATZ (Hussain et al., 2010).

In our results with rats treated with $400 \mathrm{mg} \mathrm{ATZ} / \mathrm{kg}$ bw too have been observed a significant increase of micronucleated polycromatic erythrocytes (data not published), corroborating that authors and suggesting a possible genotoxic potencial of ATZ in mammals, which have to make its use highly controlled.

\subsection{Mutagenicity and cancer}

Chronic studies of ATZ and simazine and their common metabolites show an elevated incidence of mammary tumors only in female Sprague Dawley (SD) rats. On the basis of the 
clear tumor increase in female SD rats, ATZ was proposed to be classified as a likely human carcinogen by US Environmental Protection Agency (EPA) in 1999. With Fischer rats, all strains of mice, and dogs, there was no evidence of increased incidence of ATZ -associated tumors of any type. Evidence related to the pivotal role of hormonal control of the estrus cycle in SD rats appears to indicate that the mechanism for mammary tumor induction is specific to this strain of rats and thus is not relevant to humans. In humans the menstrual cycle is controlled by estrogen released by the ovary rather than depending on the LH surge, as estrus is in SD rats. However, the relevance of the tumors to humans continues to be debated based on endocrine effects of triazines. No strong evidence exists for ATZ mutagenicity, while there is evidence of clastogenicity at elevated concentrations. ATZ does not appear to interact strongly with estrogen receptors $\alpha$ or $\beta$ but may interact with putative estrogen receptor GPR30 (G-protein-coupled receptor). A large number of epidemiologic studies conducted on manufacturing workers, pesticide applicators, and farming families do not indicate that triazines are carcinogenic in these populations. A rat-specific hormonal mechanism for mammary tumors has now been accepted by US EPA, International Agency for Research on Cancer, and the European Union. Chlorotriazines do influence endocrine responses, but their potential impact on humans appears to be primarily on reproduction and development and is not related to carcinogenesis (for revision, see Jowa \& Howd, 2011).

According an extensive review, epidemiology studies do not provide consistent, scientifically convincing evidence of a causal relationship between exposure to ATZ or triazine herbicides and cancer in humans. Based upon the assessment studies, there is no scientific basis for inferring the existence of a causal relationship between triazine exposure and the occurrence of cancer in humans (Sathiakumar et al., 2011).

A study developed by NIEHS (National Institute of Environmental Health Sciences) that extended analysis of cancer risk associated with occupational hazard of ATZ showed that there was no strong or consistent evidence of an association between ATZ and any cancer. There was a non-statistically significant increased risk of ovarian cancer related to occupational hazard for female who reported to use ATZ compared to those who did not; however, this observation was based on a small number of cases among ATZ users. The authors found an elevated risk of thyroid cancer, has not been previously reported, for the highest versus lowest category of intensity weighted ATZ use, but the trend was not monotonic and not statistically significant when lifetime days of use was considered as the exposure metric. In contrast, they observed little evidence for an association between ATZ occupational use and other cancers previously reported in the literature, such as NHL nonHodgkin lymphoma) and leukemia, or with cancers of the breast or prostate, for which ATZ has been hypothesized to be a risk factor because of its hormonal properties (Freeman et al., 2011).

Although there is conflicting information about relationship between ATZ and cancer some researches have been demonstrated preoccupation with this aspect and they highlighted the importance of many studies to confirm or not this supposition.

\section{Conclusion}

We concluded that:

- In adult model animals, lower doses of atrazine generally induce accumulation of lipids in hepatocytes, otherwise higher doses induce hepatotoxicity with degree variation 
according to animal. Amphibian tadpole's liver presents morphological response pattern, which is different those from the adult model animals.

- In rat and bird testis, atrazine has a dose-dependent adverse effects varying from no perceptible morphological changes to degeneration of seminiferous epithelium because ATZ impairs reproductive function and induces a depletion of the antioxidant defense system, according to the dose and time of exposure. Otherwise, in testis of teleost fish, amphibian and reptile, atrazine has a demascunilization/feminization effect that can be partial or complete what depends on the dose and time of exposure.

- High concentrations of atrazine induce morphological alterations in rat ovarian follicles, but not in oviduct. Induction of HSP70 in oviduct (low and high doses) could be used as exposure cell marker, as well as HSP90 depletion (high dose) or HSP90 increasing (low dose) could indicate the degree of ATZ exposure.

- In adrenal glands of rats, atrazine exposure induced varied degree of morphophysiological alterations, which is observed in a dose-dependent way due its endocrine disruptor property.

- There is not a consensus about the genotoxic effects of atrazine, and then it is necessary further studies in experimental animal models.

- Although high doses of atrazine induce clastogenicity, there is not consistent evidence that associate mutagenecity with cancer in humans.

\section{Acknowledgment}

We thank to Fundação Hermínio Ometto for financial support; to Dra. Patrícia Aline Boer for to start these researches with us and her important contribution about the kidneys; to the students Franco D. C. Pereira, Kelly L. Calisto, Patrícia M. Dias, Rafael Muniz and Silvia Takai for join us to get knowledge about effects of atrazine, and Renata Barbieri for technical assistance.

\section{References}

Abarikwu S. O., Adesiyan A. C., Oyeloja T. O., Oyeyemi M. O., Farombi e. O. (2009). Changes in Sperm Characteristics and Induction of Oxidative Stress in the Testis and Epididymis of Experimental Rats by a Herbicide, Atrazine. Arch Environ Contam Toxicol., Vol. 58, pp. 874-882

Abarikwu S.O., Farombi E.O., Kashyap M. P., Pant A. B. (2011). Atrazine induces transcriptional changes in marker genes associated with steroidogenesis in primary cultures of rat Leydig cells. Toxicol In Vitro, DOI:10.1016/j.tiv.2011.06.002.

Campero M., Ollevier F., Stoks R. (2007). Ecological relevance and sensitivity depending on the exposure time for two biomarkers. Environ Toxicol., Vol. 22, No. 6, pp. 572-81.

Cavas T. (2011). In vivo genotoxicity evaluation of atrazine and atrazine-based herbicide on fish Carassius auratus using the micronucleus test and the comet assay. Food Chem Toxicol., Vol. 49, No 6, pp. 1431-5.

Cerdeira, A. L., Dornelas-DeSouza, M., Bolonhezi, D., Queiroz, S. C. N., Ferracini, V. L., Ligo, M . A. V., Pessoa, M. C. P. Y., Smith Jr, S. (2005). Effects of Sugar Cane Mechanical Harvesting Followed by No-Tillage Crop Systems on Leaching of Triazine Herbicides in Brazil. Bull. Environ. Contam. Toxicol., Vol. 75, pp. 805812. 
Costa Silva, R. G. C., Vigna, C. R. M, Bottoli, C. B. G., Collins, C. H., Augusto, F. (2010). Molecularly imprinted silica as a selective SPE sorbent for triazine herbicides. J. Sep. Sci., Vol. 33, pp. 1319-1324.

Curic, S.; Gojmerac, T.; Zuric, M. (1999). Morphological changes in the organs of gilts induced with low-dose atrazine. Vet. Archiv., Vol. 69, pp. 135-148.

Foradori C. D., Hinds L. R., Quihuis A. M., Lacagnina A. F., Breckenridge C. B., Hand R. J. (2011). The Differential Effect of Atrazine on Luteinizing Hormone Release in Adrenalectomized Adult Female Wistar Rats. DOI:10.1095/biolreprod.111.092452

Freeman L. E. B., Rusiecki J. A., Hoppin J. A., Lubin J. H., Koutros S., Andreotti G., Zahm S. H., Hines C. J., Coble J. B., Barone-Adesi F., Sloan J., Sandler D.P., Blair A., Alavanja M. C. R. (2011). Atrazine and Cancer Incidence Among Pesticide Applicators in the Agricultural Health Study (1994-2007). DOI: 10.1289/ehp.1103561

Gluzczak, L. Miron, D.S., Moraes, B.S., Simoes, R.R. Schetinger, M.R.C., Morsch, V.M.,Loro, V.R. (2007). Acute effect of glyphosate herbicide on metabolic and enzymatic parameters of silver catfish (Rhamdia quelen). Comparative Biochemistry and Physiology., Vol. 146, pp. 519-524.

Hayes T. B., Anderson L. L., Beasley V. R., de Solla S. R., Iguchi T., Ingraham H., Kestemont P., Kniewald J., Kniewald Z., Langlois V. S., Luque E. H., McCoy K. A., Muñoz-deToro M., Oka T., Oliveira C. A., Orton F., Ruby S., Suzawa M., Tavera-Mendoza L. E., Trudeau V. L., Victor-Costa A. B., Willingham E. (2011). Demasculinization and feminization of male gonads by atrazine: Consistent effects across vertebrate classes. J Steroid Biochem Mol Biol., DOI:10.1016/j.jsbmb.2011.03.015.

Juliani, C.C.; Silva-Zacarin, E.C.M.; Carvalho, D., Boer, P. A. (2008). Effects of atrazine on female Wistar rats: morphological alterations in ovarian follicles and immunocytochemical labeling of $90 \mathrm{kDa}$ heat shock protein. Micron, Vol. 30, pp. 607-616.

Jowa L., Howd R. (2011). Should atrazine and related chlorotriazines be considered carcinogenic for human health risk assessment? J Environ Sci Health C Environ Carcinog Ecotoxicol Rev., Vol. 29, No 2, pp. 91-144.

Lim S., Ahn S. Y., Song I. C., Chung M. H., Jang H. C., Par K. S., Lee K., Pak Y. K., Lee H. K. (2009). Chronic Exposure to the Herbicide Atrazine Causes Mitochondrial Dysfunction and Insulin Resistance. PLOS ONE, Vol. 4, No 4, pp. 1-11

Mariani, M. L.; Souto, M.; Fanelli, M. A., Ciocca, D. R. (2000). Constitutive expression of heat shock proteins hsp25 and hsp70 in the rat oviduct during neonatal development, the oestrous cycle and early pregnancy. Journal of Reproduction and Fertility, Vol. 120, No 2, pp. 217-223.

Mudiam, M. K. R., Pathak, S. P., Gopal, K., Murthy, R. C. (2011). Studies on urban drinking water quality in a tropical zone. Environ. Monit. Acess., DOI 10.1007/s10661-0111980-3.

Mohammad M., Itoh K. (2011). New Concept for Evaluating the Toxicity of Herbicides for Ecological Risk Assessment, In: Herbicides and Environment., Andreas Kortekamp, pp. 561-582, InTech Open Access Publisher, Retrieved from www.intechweb.org/books/show/title/herbicides-and-environment, ISBN 978953-307-476-4. 
Nwani C.D., Lakra W.S., Nagpure N.S., Kumar R., Kushwaha B and Srivastava S.K. (2010). Toxicity of the herbicide atrazine: effects on lipid peroxidation and activities of antioxidant enzymes in the freshwater fish Channa punctatus (Bloch). Int J Environ Res Public Health, Vol. 8, pp. 3298-312.

Pogrmic-Majkic K., Fa S., Dakic V., Kaisarevic S., Kovacevic R. (2010). Upregulation of Peripubertal Rat Leydig Cell Steroidogenesis Following $24 \mathrm{~h}$ In Vitro and In Vivo Exposure to Atrazine. Toxicol.Sci., Vol. 118, No 1, pp. 52-60.

Ralston-Hooper, K., Hardy, J., Hahn, L., Ochoa-Acuña, H., Lee, L.S., Mollenhauer, R., Maria S. Sepúlveda, M.S. (2009). Acute and chronic toxicity of atrazine and its metabolites deethylatrazine and deisopropylatrazine on aquatic organisms. Ecotoxicol., Vol. 18, No 7, pp. 899-905.

Rey F., González M., Zayas M. A., Stoker C., Durando M., Luque e. H., Muñoz-de-Toro M. (2009). Prenatal exposure to pesticides disrupts testicular histoarchitecture and alters testosterone levels in male Caiman latirostris. General and Comparative Endocrinology, Vol. 162, pp. 286-292

Hussain R., Mahmood F., Khan M. Z., Khan A., Muhammad F. (2011). Pathological and genotoxic effects of atrazine in male Japanese quail (Coturnix japonica). Ecotoxicology, Vol. 20, pp. 1-8

Ross, M. K., Jones, T. L., Filipov, N. M. (2009). Disposition of the Herbicide 2-Chloro-4(ethylamino)-6-(isopropylamino)-s-triazine (Atrazine) and Its Major Metabolites in Mice: A Liquid Chromatography/Mass Spectrometry Analysis of Urine, Plasma, and Tissue Levels. Drug Metabolism and Disposition, Vol. 37, pp. 776-786.

Saal F. S. and Welshons W. V. (2006). Large effects from small exposures. II. The importance of positive controls in low-dose research on bisphenol A. Environ Res., Vol. 100, No. 1, pp. 50-76.

Sathiakumar N., MacLennan P. A., Jack Mandel, Delzell E. (2011). A review of epidemiologic studies of triazine herbicides and cancer. Critical Reviews in Toxicology, Vol. 41, No. 1, pp. 1-34

Sifakis S., Mparmpas M., Soldin O. P., Tsatsakis A. (2011). Pesticide Exposure and Health Related Issues in Male and Female Reproductive System. In: Pesticides Formulations, Effects, Fate. Margarita Stoytcheva, pp. 495-526, InTech Open Access Publisher, Retrieved from www.intechweb.org/books/show/title/pesticidesformulations-effects-fate, ISBN 978-953-307-532-7.

Taketa Y., Yoshida M., Inoue K., Takahashi M., Sakamoto Y., Watanabe G., Taya K., Yamate J., Nishikawa A. (2011). Differential stimulation pathways of progesterone secretion from newly formed corpora lutea in rats treated with ethylene glycol monomethyl ether, sulpiride, or atrazine. Toxicol Sci., Vol. 121, No. 2, pp. 267-78.

Thornton B. J., Elthon T. E., Cerny R. L., Siegfried B. D. (2010). Proteomic analysis of atrazine exposure in Drosophila melanogaster (Diptera: Drosophilidae). Chemosphere, Vol. 81, No. 2, pp. 235-41.

Yuanxiang J., Xiangxiang Z., Dezhao L., Zhengwei F. (2011). Proteomic Analysis of Hepatic Tissue in Adult Female Zebrafish (Danio rerio) Exposed to Atrazine. Arch Environ Contam Toxicol., DOI 10.1007/s00244-011-9678-7

Zaya R. M., Amini Z., Whitaker A. S., Kohler S. L., Ide C. F. (2011). Atrazine exposure affects growth, body condition and liver health in Xenopus laevis tadpoles. Aquat Toxicol., Vol. 104, No. 3-4, pp. 243-53. 


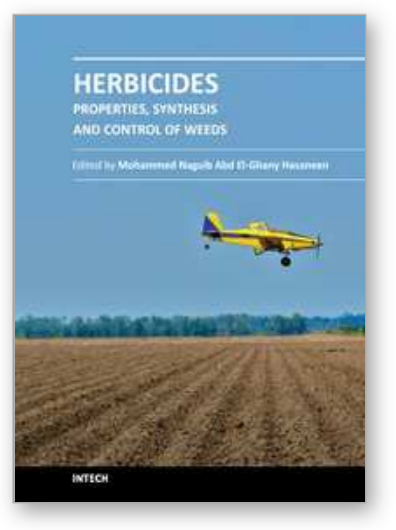

\author{
Herbicides - Properties, Synthesis and Control of Weeds \\ Edited by Dr. Mohammed Nagib Hasaneen
}

ISBN 978-953-307-803-8

Hard cover, 492 pages

Publisher InTech

Published online 13, January, 2012

Published in print edition January, 2012

This book is divided into two sections namely: synthesis and properties of herbicides and herbicidal control of weeds. Chapters 1 to 11 deal with the study of different synthetic pathways of certain herbicides and the physical and chemical properties of other synthesized herbicides. The other 14 chapters (12-25) discussed the different methods by which each herbicide controls specific weed population. The overall purpose of the book, is to show properties and characterization of herbicides, the physical and chemical properties of selected types of herbicides, and the influence of certain herbicides on soil physical and chemical properties on microflora. In addition, an evaluation of the degree of contamination of either soils and/or crops by herbicides is discussed alongside an investigation into the performance and photochemistry of herbicides and the fate of excess herbicides in soils and field crops.

\title{
How to reference
}

In order to correctly reference this scholarly work, feel free to copy and paste the following:

Grasiela D.C. Severi-Aguiar and Elaine C.M. Silva-Zacarin (2012). Effects of Herbicide Atrazine in Experimental Animal Models, Herbicides - Properties, Synthesis and Control of Weeds, Dr. Mohammed Nagib Hasaneen (Ed.), ISBN: 978-953-307-803-8, InTech, Available from:

http://www.intechopen.com/books/herbicides-properties-synthesis-and-control-of-weeds/effects-of-herbicideatrazine-in-experimental-animal-models

\section{INTECH}

open science | open minds

\section{InTech Europe}

University Campus STeP Ri

Slavka Krautzeka 83/A

51000 Rijeka, Croatia

Phone: +385 (51) 770447

Fax: +385 (51) 686166

www.intechopen.com

\section{InTech China}

Unit 405, Office Block, Hotel Equatorial Shanghai

No.65, Yan An Road (West), Shanghai, 200040, China

中国上海市延安西路65号上海国际贵都大饭店办公楼 405 单元

Phone: +86-21-62489820

Fax: $+86-21-62489821$ 
(C) 2012 The Author(s). Licensee IntechOpen. This is an open access article distributed under the terms of the Creative Commons Attribution 3.0 License, which permits unrestricted use, distribution, and reproduction in any medium, provided the original work is properly cited. 